HRD and the Emergence of Social Finance as a Driver for Social Change.

\author{
Robert M. Yawson \\ Quinnipiac University
}

robert.yawson@qu.edu

A Poster Presentation

Copyright (C2020 Robert M Yawson 


\begin{abstract}
The purpose of this research is to determine the role of Human Resource Development (HRD) in this emerging field of Social Finance. HRD researchers must move beyond the boundaries of performance and include voices that are missing from the discourse on Social Finance. The main research question this study seeks to answer is: What role should and can Human Resource Development play in the brave new world of Social Finance. Through financial technology disruption, and emerging technologies like Blockchain, Artificial Intelligence, the Internet of Things, among others, and the urgent need to fill 2.5 trillion USD gap to achieve the SDGs, the pace of change is likely to accelerate. HRD has a vital role to play in this Brave New World of Social Finance. Attending to the human and developmental aspects of social finance organizations should be a critical issue for HRD.

Keywords: Social Change, UN SDGs, Social Finance
\end{abstract}




\section{Paper's importance}

Social finance is trendsetting, a buzzword and a phenomenon that has gained considerable interest, becoming an often discussed topic in conferences, seminars, corporate training workshops, scholarly journals, universities, governments, municipalities, publishing houses, social media, etc. It is also "a rapidly advancing area of practice, policy, and research, with a lot of unanswered questions" (Nicholls, Paton, \& Emerson, 2015). There is, however, nothing in the HRD literature on social finance. While there exists in the HRD extant literature, a fair amount of studies on HRD's role in Corporate Social Responsibility (CSR), philanthropy, sustainability, and international development, it is critically important that the role of HRD is established in the brave new world of social finance.

\section{Theoretical base}

Despite the enormous discussions and the ubiquitous use of the term social finance, there is no broadly accepted definition of what it is and what it incorporates (Rexhepi, 2017). There are, however, many definitions of social finance. The common theme throughout all these definitions is that it is oriented toward investments flows through which an organization tries to generate financial returns for sustainability by solving the world's most complex challenges. Investments are generated from private investors and governments, which, through social finance, create profit and bring social good for all. Nicholls et al. (2015) expounded that social finance can be seen as the discourse around investments flows that is developing in concrete terms in the new institutions of supply, intermediation, and demand and pointed out that the discourse is in a flux with competing perspectives driving the debate.

The discourse that has emanated from this common understanding is about the differences between social finance and micro-finance, social investments, Corporate Social Responsibility, and not-for-profit charity work. As Massetti (2012) has indicated, social finance is conceptually a very different approach to micro-finance, Corporate Social Responsibility, and not-for-profit charity work, which can all be grouped under social welfare enhancement. Social finance, on the other hand, uses some ideas of neoliberal markets to drive social change, and it is increasing the need for social and environmental improvements, with a vast potential to make a tremendously positive impact on the economy (Rexhepi, 2017). Social finance secures 
its own sustainability by being profitable, and it is not necessarily created by government or through donations but also by using personal funds, bonds, borrowing, taking microloans, etc. Unlike microfinance, which is primarily a form of crediting, social finance is a form of investment. However, some organizations like the International Labor Office (ILO) see microfinance as a form of social finance (ILO, 2010). Nicholls et al. (2015) differentiate between social finance and social investment, explaining that social investment is a narrower alternative to social finance which is more of the full range of instruments, hybrid funding models, and structured deals blending various types of capital that are evident across philanthropic donations; government grants; 'soft' return debt and equity; mutual finance; as well as 'finance first' and 'total portfolio' impact investing strategies.

In this study, I use the term 'social finance' as a very broad set of investment activities that generate financial returns and consider social and environmental impact (Hangl, 2014; High Meadows Institute, 2015; Nicholls et al., 2015; Varga \& Hayday, 2016).

\section{Research purpose}

Social finance has different organizational intents oriented toward using the power of the marketplace to solve social and environmental problems (Massetti, 2012). It creates fundamentally different kinds of organizations, helps them stay true to their mission, and encourages various types of ownership. Moreover, social finance challenges the institutional logics associated with conventional investor rationalities by separating the logics of value creation and value appropriation (Nicholls, 2012). Social finance represents the emergence of new models, which are oriented mainly toward not only solving some social problems but also gaining a reasonable profit. The purpose of this research is, therefore, to determine the role of Human Resource Development (HRD) in this emerging field of Social Finance. "HRD researchers must approach the knowledge creation process more critically through challenging traditional research designs, asking questions that move beyond the boundaries of performance and including voices that are missing from the discourse" on Social Finance (Bierema \& D'Abundo, 2004). 


\section{Research question}

The main research question this study seeks to answer is: What role should and can Human Resource Development play in the brave new world of Social Finance

\section{Implications for HRD practice}

Rexhepi (2017) categorized the social finance market into three segments: demand side, comprising actors who need social finance; the supply side, the providers of social finance; and intermediators that connect social actors who need additional capital with private actors who can supply capital.

\section{Figure 1. Overview of Social Finance Marketplace}

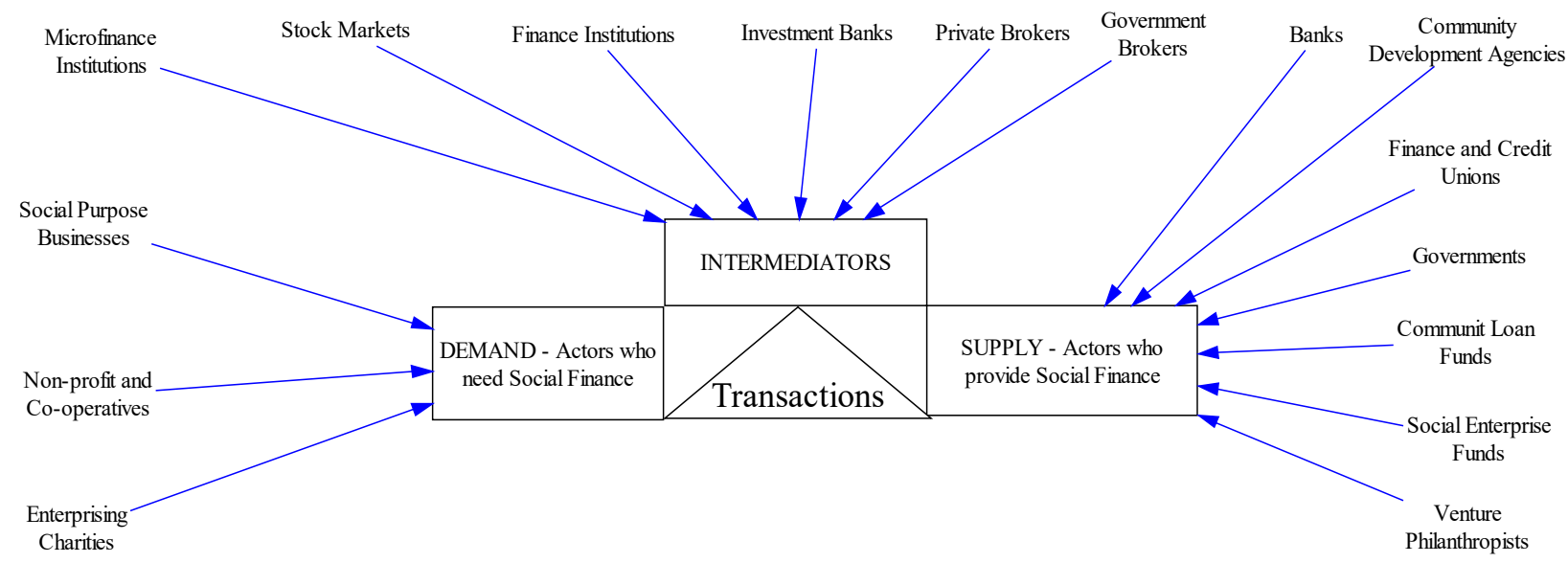

Source: Adapted and Re-drawn from Rexhepi (2017)

Figure 1 depicts an overview of social finance and the way this market operates. The role of government in social finance has been critical and as noted by Myers and Conte (2013) governments can be actors on both the supply and demand sides of the social finance marketplace. Intermediators, as depicted in Figure 1, are institutions that help investors invest their money in the demand side for social purposes. HRD should be at the intersection of all these social and private actors in the social finance ecosystem with what Bierema and D'Abundo (2004) describe as socially conscious HRD.

Social finance has been heralded as a driver for social change and social good. It is framed as an attempt to "humanize" or re-moralize capitalism by utilizing financial markets to tackle social problems (Berndt \& Wirth, 2018). Proponents of social finance are of the conviction that many people will be earning a good amount of money instead of just a small group of people getting very rich. Social finance also 
influences social innovation and social entrepreneurship, which can solve many problems of today's economic system. Social finance approaches enable governments to "share the risks" with the private sector. It also helps governments improve outcomes by aligning interests so that capital is channeled toward the most effective interventions. Similar issues HRD is confronted.

Just like any other innovations and advances, there also those who are very critical of social finance. While dedication to social finance to solve social and environmental problems increases among governments and the networks of supporting organizations, broader opinion on the merits of the various forms of social finance like development bonds are divided (Dey \& Gibbon, 2018). "The scope and depth of the critique emerging from this literature suggest that the claims being made about the potential role of impact bonds in addressing fundamental societal, developmental and environmental problems are often exaggerated." (Dey \& Gibbon, 2018). It has been argued in some of the academic literature that social finance has the potential of increasing economic insecurity, accentuating inequality trends and exacerbating vulnerability especially in the global south (Lavinas, 2018). This critique is predicated on the belief that social finance is 'financialized' capitalism that is radically subverting the role and logic of social policy, which raises concerns of re-commodification replacing de-commodification; and debt, through financial inclusion, now serving as an alternative to exclusion (Lavinas, 2018). It has also been argued that social finance is a "co-imbrication between the state and the financial sector in which the state is using finance to intervene in society in ways that ostensibly seek to reduce costs and welfare dependency, while at the same time the state is used as a vehicle for financial capital accumulation."(Dowling, 2017). Another critique of social finance is that it is a way "marginalized people are converted into commodities and re-packaged as derivatives by investors plying their trade in the new marketplace of inequality" (Neyland, 2018). HRD cannot be left out of these dialogue relating human and development with the potential of bringing a new social order.

\section{Conclusions}

Despite the critiques, social finance is here to stay and just like other ecosystems; it is not static; it is dynamic and continually adapting to change (Varga \& Hayday, 2016). Through financial technology 
disruption, and emerging technologies like Blockchain, Artificial Intelligence, the Internet of Things, among others, and the urgent need to fill 2.5 trillion USD gap to achieve the SDGs, the pace of change is likely to accelerate. Human Resource Development has an important role to play in this Brave New World of Social Finance. Attending to the human and developmental aspects of social finance organizations should be a critical issue for HRD. 


\section{References}

Berndt, C., \& Wirth, M. (2018). Market, metrics, morals: The Social Impact Bond as an emerging social policy instrument. Geoforum, 90(January), 27-35. https://doi.org/10.1016/j.geoforum.2018.01.019

Bierema, L. L., \& D’Abundo, M. L. (2004). HRD with a conscience: Practicing socially responsible HRD. International Journal of Lifelong Education, 23(5), 443-458.

https://doi.org/10.1080/026037042000293416

Dey, C., \& Gibbon, J. (2018). New development: Private finance over public good? Questioning the value of impact bonds. Public Money \& Management, 38(5), 375-378.

https://doi.org/10.1080/09540962.2018.1477676

Dowling, E. (2017). In the wake of austerity: social impact bonds and the financialisation of the welfare state in Britain. New Political Economy, 22(3), 294-310.

https://doi.org/10.1080/13563467.2017.1232709

Hangl, C. (2014). A Literature Review About the Landscape of Social Finance. ACRN Journal of Finance and Risk Perspectives, 3(4), 64-98.

High Meadows Institute. (2015). Social Finance Industry Snapshot \& Forecast. Boston, MA.

ILO. (2010). Social Finance. In C. Churchill (Ed.), EMPLOYMENT FOR SOCIAL JUSTICE AND A FAIR GLOBALIZATION. Overview of ILO programmes (p. 2). Geneva, Switzerland: Social Finance Programme, Employment Sector, International Labour Office.

Lavinas, L. (2018). The Collateralization of Social Policy under Financialized Capitalism. Development and Change, 49(2), 502-517. https://doi.org/10.1111/dech.12370

Massetti, B. (2012). The Duality of Social Enterprise: A Framework for Social Action. Review of Business, 33(1), 50-65.

Myers, K., \& Conte, N. (2013). Can social finance improve the outcomes of employment and training programs? Ottawa, Ontario: The Social Research and Demonstration Corporation (SRDC).

Retrieved from http://www.srdc.org/media/199684/social-finance-paper.pdf

Neyland, D. (2018). On the transformation of children at-risk into an investment proposition: A study of 
Social Impact Bonds as an anti-market device. The Sociological Review, 66(3), 492-510.

https://doi.org/10.1177/0038026117744415

Nicholls, A. (2012). The legitimacy of social entrepreneurship: Reflexive Isomorphism in a preparadigmatic field. Social Enterprises: An Organizational Perspective, 44(0), 222-247. https://doi.org/10.1057/9781137035301_11

Nicholls, A., Paton, R., \& Emerson, J. (2015). Social Finance. (A. Nicholls, R. Paton, \& J. Emerson, Eds.). Oxford, UK: Oxford University Press.

https://doi.org/10.1093/acprof:oso/9780198703761.001.0001

Rexhepi, G. (2017). The Architecture of Social Finance. In O. M. Lehner (Ed.), Routledge Handbook of Social and Sustainable Finance (pp. 35-49). London, UK: Routledge. https://doi.org/10.4324/9781315772578.ch3

Varga, E., \& Hayday, M. (2016). A Recipe for Social Finance. A practical guide on designing and implementing initiatives to develop social finance instruments and markets. Luxembourg: EUROPEAN COMMISSION, Directorate-General for Employment, Social Affairs and Inclusion Directorate E — Skills. https://doi.org/10.1093/acprof 